\title{
Transformacja cyfrowa- szanse i wyzwania dla przedsiębiorstw
}

\begin{abstract}
Streszczenie
Artykuł prezentuje główne komponenty transformacji cyfrowej: jej czynniki zewnętrze, fazy oraz czynniki strategiczne. Wskazuje na wymiary transformacji cyfrowej w łańcuchu generowania wartości dodanej przedsiębiorstwa w oparciu o posiadane aktywa, dane pozyskane na podstawie użytkowania produktów oraz od konsumentów, a także cele i miary. Na podstawie zmodyfikowanej postaci modelu Davida J. Teece’a scharakteryzowana została rola platform cyfrowych, ekosystemu, komplementarności oraz standardów w czerpaniu korzyści z innowacji. W artykule wyróżnione zostały podstawowe strategie rozwoju dla firm, które stosują strategie oparte na platformach, a mianowicie: rozwój rynku oparty na platformie, współtworzenie klientów i dywersyfikacja platformy. Artykuł prezentuje definicję kluczowych kategorii na podstawie przeglądu odnośnej literatury przedmiotu oraz przywołuje wybrane przykłady ilustrujące omawiane kategorie i zależności.

Słowa kluczowe: cyfryzacja, innowacja cyfrowa, platforma cyfrowa, ekosystem
\end{abstract}

Prof. dr hab. Paweł Kawalec, profesor w Katedrze Teorii Poznania w Instytucie Filozofii na Wydziale Filozofii Katolickiego Uniwersytetu Lubelskiego Jana Pawła II; e-mail: pawel.kawalec@kul.pl; ORCID: 0000-0001-7618-8298. 
Wprowadzenie

Transformacja cyfrowa jest zjawiskiem, które prowadzi do kompleksowej i fundamentalnej modyfikacji dotychczasowego funkcjonowania przedsiębiorstw. Niniejszy artykuł koncentruje się na całościowej charakterystyce transformacji cyfrowej przez wskazanie na jej czynniki zewnętrze, fazy oraz czynniki strategiczne. Określone są wymiary transformacji cyfrowej w łańcuchu generowania wartości dodanej przedsiębiorstwa na bazie posiadanych aktywów, dane pozyskane na podstawie użytkowania produktów oraz od konsumentów, a także cele i miary. W odniesieniu do zmodyfikowanej postaci modelu Davida J. Teece’a nakreślona została rola platform cyfrowych, ekosystemu, komplementarności oraz standardów w czerpaniu korzyści z innowacji. W artykule rozróżniono podstawowe strategie rozwoju dla firm, które stosują strategie oparte na platformach, a mianowicie: rozwój rynku oparty na platformie, współtworzenie klientów i dywersyfikacja platformy. Artykuł przedstawia definicję kluczowych kategorii na podstawie przeglądu odnośnej literatury przedmiotu oraz przywołuje wybrane przykłady ilustrujące omawiane kategorie i zależności.

\section{Główne fazy transformacji cyfrowej}

Innowacje cyfrowe istotnie wpłynęły na modyfikację zachowań i oczekiwań konsumentów, a także na działalność przedsiębiorstw i ich zdolności dynamiczne. Zmiany te nie tylko wywierają presję na tradycyjny sposób prowadzenia działalności gospodarczej i wcześniej funkcjonujące modele biznesowe, ale mają obecnie charakter strukturalny, co zbiorczo określa się terminem „transformacji cyfrowej”. Transformacja cyfrowa jest zjawiskiem zauważalnym na poziomie całej gospodarki, co jest ujawniane w analizach makroekonomicznych (Tiutiunyk i in., 2021), wskazujących również na wzrastający poziom nierówności między krajami o różnym poziomie rozwoju technologicznego (Wiktor, Dado, Simberova, 2021; Wysokińska, 2021). W zasadniczy sposób zmianie uległ także dotychczasowy model dyskontowania korzyści z innowacji (Kawalec, 2013; Teece, 1986), gdyż wobec dotychczasowych rynków transformacja cyfrowa prowadzi do ich istotnego zakłócenia. $\mathrm{Na}$ poziomie pojedynczych przedsiębiorstw wiele znanych marek ustępuje miejsca na rynku nowym podmiotom, które skuteczniej wykorzystują innowacje cyfrowe oraz posługują się innowacyjnymi modelami biznesowymi. Amazon, który jest jednym z najszybciej rozwijających się nowych podmiotów, wypiera z rynku tradycyjnych sprzedawców detalicznych, którzy dotychczas dominowali i mieli status podmiotów zasiedziałych, jak Toys R'Us czy RadioShack. Ponadto model biznesowy Amazona 
znacznie wykracza poza sprzedaż detaliczną, stanowiąc zagrożenie dla podmiotów z sektorów pozornie niezwiązanych bezpośrednio ze sprzedażą detaliczną, jak bankowość. Inne znane przykłady zakłócenia działalności dotychczasowych rynków wskutek transformacji cyfrowej to sprzedaż utworów muzycznych (iTunes firmy Apple, Spotify), produkcja i dystrybucja filmów (Netflix), działalność hotelarska (AirBnB) czy transportowa (Uber).

Ogólnie transformację cyfrową definiuje się (Schallmo, Williams, Boardman, 2020; Verhoef i in., 2021) jako przekształcenie sposobu wykorzystania technologii cyfrowych w celu stworzenia nowego modelu biznesowego, który wspomaga kreowanie wartości dodanej oraz zwiększa efektywność jej wykorzystania przez przedsiębiorstwo (M. Jabłoński, A. Jabłoński, Szpitter, 2020). Aby uchwycić, w jaki sposób przedsiębiorstwa mogą uzyskać trwałą przewagę konkurencyjną dzięki transformacji cyfrowej, konieczne jest określenie, jakie strategie powinny przyjąć, by wykorzystując określone zasoby, mogły uzyskać przewagę konkurencyjną, oraz w jaki sposób ich wewnętrzna struktura organizacyjna ma się zmienić (Batko, Baliga-Nicholson, 2019). Schematycznie zależność poszczególnych zagadnień w odniesieniu do transformacji cyfrowej przedstawia rysunek 1 (Parker, Van Alstyne, Jiang, 2016).

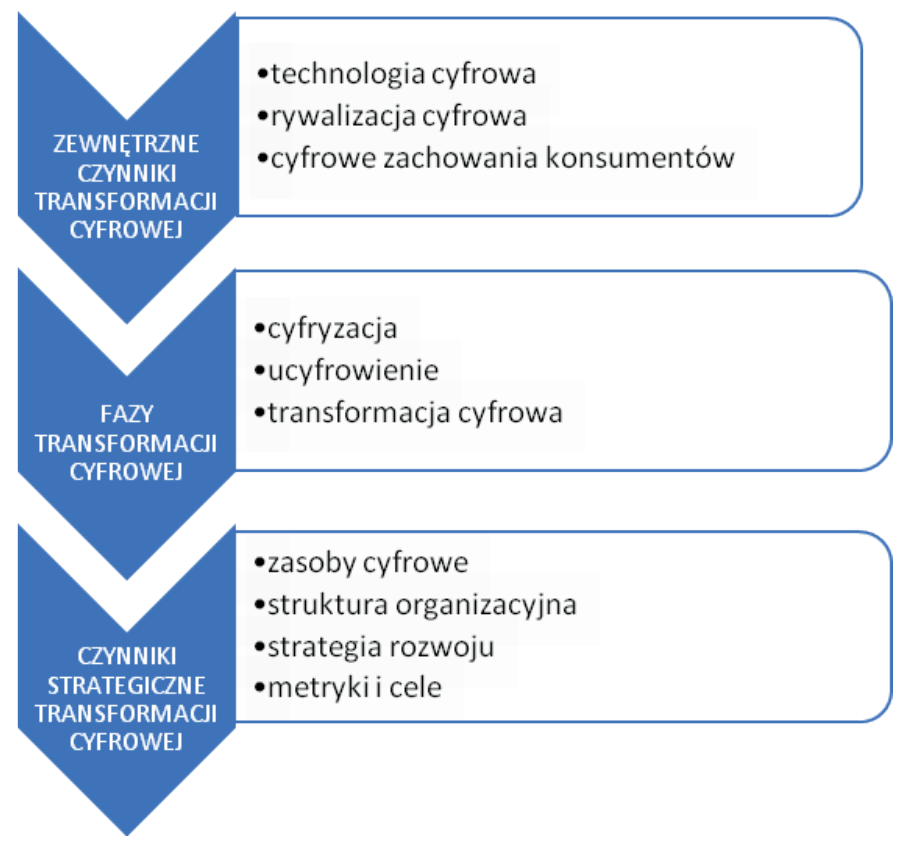

Rysunek 1. Model przepływu dla transformacji cyfrowej

Źródło: opracowanie własne na podstawie Verhoef i in., 2021. 
W literaturze przedmiotu identyfikuje się trzy rodzaje czynników zewnętrznych, które wpływają na zjawisko transformacji cyfrowej (Smulski, 2020). Pierwszy z nich obejmuje nowe technologie. Ich powstanie zostało zapoczątkowane przez stworzenie serwisu internetowego World Wide Web, który w krótkim czasie znalazł dużą liczbę użytkowników. Stał się on zaczątkiem powstawania powiązanych technologii, jak systemy płatności online, internet szerokopasmowy, chmury obliczeniowe, smartfony czy kryptowaluty, które stały się istotnym wsparciem dla sprzedaży elektronicznej e-commerce, wykorzystującej internet, która według danych Statista wykazuje bardzo dynamiczny wzrost z poziomu 1300 mld dolarów w 2014 roku do poziomu 4280 mld dolarów w 2020 roku i obejmuje 18\% sprzedaży detalicznej ogółem.

Zjawisko transformacji cyfrowej znacząco zwiększyło swoją intensywność wskutek pandemii COVID-19 (Polska Agencja Rozwoju Przedsiębiorczości [PARP], 2021), w związku z czym nowe technologie będą nabierać jeszcze większego znaczenia również w przyszłości. Należy tu zwrócić uwagę przede wszystkim na sztuczną inteligencję, blockchain, Internet Rzeczy (ang. Internet of Things - IoT) oraz robotykę, które wobec coraz powszechniejszego dostępu do sieci 5G będą miały istotne znaczenie dla sposobu prowadzenia działalności gospodarczej, w tym również dla struktury kosztów. Oczekuje się, że koszty wynagrodzeń dla pracowników znacznie spadną, zwłaszcza w obszarze świadczenia usług, w związku z wprowadzeniem robotów lub agentów wirtualnych, a także w obszarze logistyki oraz kosztów w łańcuchu dostaw, przede wszystkim w związku z wykorzystaniem sztucznej inteligencji i technologii blockchain.

Drugim zewnętrznym czynnikiem transformacji cyfrowej są istotne zmiany w konkurencji przedsiębiorstw. Nabrała ona bardziej globalnego charakteru i stała się bardziej intensywna w związku z poszerzaniem zakresu działalności gigantów technologicznych ze Stanów Zjednoczonych (zwłaszcza Amazon, Alphabet, Apple oraz Facebook) i Chin (głównie Alibaba oraz JD), wykorzystujących duże ilości danych (ang. big data) w celu dominacji w coraz to nowych sektorach działalności. Tę przemianę ilustrują choćby zmiany w składzie największych spółek notowanych w indeksie S\&P 500.

Tabela 1. Zmiany składu indeksu S\&P 500

\begin{tabular}{cc}
\hline 2011 & ExxonMobil, Apple, Microsoft, IBM, Chevron \\
\hline 2021 & Microsoft, Apple, Amazon, Alphabet, Tesla \\
\hline
\end{tabular}

Źródło: opracowanie własne. 
Trzecim czynnikiem jest zmiana zachowań konsumentów jako odpowiedź na wprowadzanie na rynek innowacji cyfrowych. Zachowania uległy istotnym zmianom pod wpływem m.in. mediów społecznościowych oraz wykorzystania wyszukiwarek internetowych, co wpłynęło na zwiększenie wzajemnego powiązania zachowań konsumentów, ich bardziej aktywny charakter oraz pełniejsze wykorzystanie informacji. Ponadto technologie cyfrowe otwierają nowe możliwości działania dla konsumentów, jak np. projektowanie czy dostosowywanie produktów dla potrzeb indywidualnych, realizacja dostaw na ostatnim odcinku dostarczania towaru do odbiorcy końcowego czy ukierunkowywanie działań innych konsumentów przez publiczne udostępnianie opinii o produktach lub usługach.

Kolejnym istotnym aspektem transformacji cyfrowej są jej fazy. Peter C. Verhoef i współpracownicy (2021) wyodrębniają trzy fazy transformacji cyfrowej: cyfryzację, ucyfrowienie oraz transformację cyfrową. Zasadniczo dwie pierwsze fazy charakteryzuje stopniowe ulepszanie aktualnego funkcjonowania przedsiębiorstwa, natomiast faza ostatnia, transformacja cyfrowa, prowadzi do jego całościowego przekształcenia (Parviainen i in., 2017).

Cyfryzacja (ang. digitization) dotyczy przede wszystkim procesu tworzenia i opracowywania dokumentacji, gdyż polega ona na przekształceniu informacji w wersji analogowej do postaci cyfrowej, dzięki czemu możliwe jest jej przetwarzanie za pomocą komputerów, jak również jej przechowywanie i przesyłanie. Umożliwia to $\mathrm{z}$ kolei rekonfigurację posiadanych przez przedsiębiorstwo zasobów z wykorzystaniem technologii IT. Przykładem jest użycie elektronicznych formularzy do realizacji zamówień klientów, zastosowanie w badaniach marketingowych ankiet elektronicznych oraz wprowadzenie zautomatyzowanych procedur i zadań (Kotler, Kartajaya, Setiawan, 2021). Cyfryzacja więc nie jest bezpośrednio związana z tworzeniem wartości dodanej, lecz jest zorientowana na zmniejszenie kosztów działalności operacyjnej. Miarą cyfryzacji są standardowe, kluczowe wskaźniki efektywności, np. ROI czy ROA.

Ucyfrowienie (ang. digitalization) polega $\mathrm{z}$ kolei na zastosowaniu technologii IT jako czynnika umożliwiającego wykorzystanie nowych możliwości biznesowych poprzez zmodyfikowanie dotychczasowych procesów w przedsiębiorstwie, takich jak komunikacja czy dystrybucja. Celem tej modyfikacji jest zwiększenie optymalizacji tych procesów, zwiększenie stopnia ich wzajemnego skoordynowania, a dzięki temu również stworzenie wartości dodanej dla klienta oraz poprawa doświadczeń użytkowników. Przykładem ucyfrowienia jest stworzenie nowych kanałów kontaktu z przedsiębiorstwem, wykorzystujących internet lub aplikacje mobilne, co znacznie zwiększa poziom interaktywności w relacjach między konsumentem a przedsiębiorstwem. Innym przykładem 
jest zastosowanie robotów w produkcji, dodanie komponentów cyfrowych do oferty produktów lub usług czy wprowadzenie cyfrowych kanałów dystrybucji i komunikacji. Oprócz tradycyjnych KPI wskaźnikami ucyfrowienia będą cyfrowe KPI, jak np. doświadczenie użytkownika, unikalni klienci/użytkownicy czy aktywni klienci/użytkownicy.

Natomiast transformacja cyfrowa jest całościowym przekształceniem dotychczasowego sposobu funkcjonowania przedsiębiorstwa, gdyż wiąże się ona z opracowaniem i wdrożeniem nowego modelu biznesowego. Obejmuje więc ona sposób tworzenia wartości dodanej oraz dostarczania jej klientom, a następnie przekształcania pozyskanych środków na zyski. W przeciwieństwie do ucyfrowienia transformacja cyfrowa nie obejmuje wyłącznie pojedynczych procesów organizacyjnych i zadań, lecz prowadzi do przekształcenia dotychczasowej logiki funkcjonowania przedsiębiorstwa lub sposobu tworzenia przez nie wartości dodanej. Transformacja cyfrowa może pozwolić na uzyskanie przewagi konkurencyjnej poprzez przekształcenie organizacji, by lepiej wykorzystać istniejące kluczowe kompetencje lub rozwinąć nowe, dlatego transformacja cyfrowa jest nieodłącznie powiązana ze strategicznymi zmianami modelu biznesowego w wyniku wdrożenia technologii cyfrowych (Sebastian i in., 2020). Przykładem transformacji cyfrowej w tej ostatniej fazie może być wprowadzenie nowych modeli biznesowych, takich jak „produkt jako usługa", zastosowanie platform cyfrowych czy opracowanie modeli biznesowych opartych wyłącznie na danych. Przykładami wskaźników transformacji cyfrowej w tej fazie mogą być takie cyfrowe KPI, jak udział cyfrowy, dynamika cyfrowa czy sentyment współtwórcy.

Syntetyczną charakterystykę trzech faz podaje tabela 2. Różne fazy zmian cyfrowych w kierunku transformacji cyfrowej mają dla firm ważne imperatywy strategiczne. Ich wpływ na zasoby cyfrowe, strukturę organizacyjną, strategie rozwoju cyfrowego oraz cele zostały zestawione także w tabeli 2 .

Tabela 2. Charakterystyka trzech faz transformacji cyfrowej

\begin{tabular}{clccc}
\hline $\begin{array}{c}\text { Faza transformacji } \\
\text { cyfrowej }\end{array}$ & Zasoby cyfrowe & $\begin{array}{c}\text { Struktura } \\
\text { organizacyjna }\end{array}$ & $\begin{array}{c}\text { Strategie rozwoju } \\
\text { cyfrowego }\end{array}$ & Cel \\
\hline Cyfryzacja & aktywa cyfrowe & $\begin{array}{c}\text { standardowa } \\
\text { hierarchiczna }\end{array}$ & $\begin{array}{c}\text { penetracja rynku } \\
\text { (bazująca na pro- } \\
\text { duktach); } \\
\text { rozwój rynku; }\end{array}$ & $\begin{array}{c}\text { oszczędność kosz- } \\
\text { tów: bardziej efek- } \\
\text { tywne rozdyspono- } \\
\text { wanie zasobów wśród } \\
\text { istniejących działań }\end{array}$ \\
\hline
\end{tabular}




\begin{tabular}{|c|c|c|c|c|}
\hline $\begin{array}{c}\text { Faza transformacji } \\
\text { cyfrowej }\end{array}$ & Zasoby cyfrowe & $\begin{array}{c}\text { Struktura } \\
\text { organizacyjna }\end{array}$ & $\begin{array}{l}\text { Strategie rozwoju } \\
\text { cyfrowego }\end{array}$ & Cel \\
\hline Ucyfrowienie & $\begin{array}{l}\text { [powyższe oraz] } \\
\text { cyfrowa spraw- } \\
\text { ność (ang. agility), } \\
\text { zdolność do } \\
\text { networkingu } \\
\text { cyfrowego }\end{array}$ & $\begin{array}{l}\text { oddzielne, zwinne } \\
\text { jednostki }\end{array}$ & $\begin{array}{l}\text { [powyższe oraz] } \\
\text { penetracja rynku } \\
\text { oparta na platfor- } \\
\text { mach, platforma } \\
\text { współtworzenia }\end{array}$ & $\begin{array}{l}\text { oszczędność kosztów } \\
\text { i zwiększone } \\
\text { przychody: } \\
\text { bardziej wydajna } \\
\text { produkcja dzięki } \\
\text { reorganizacji procesów } \\
\text { biznesowych; } \\
\text { lepsze doświadczenie } \\
\text { klienta }\end{array}$ \\
\hline $\begin{array}{c}\text { Transformacja } \\
\text { cyfrowa }\end{array}$ & $\begin{array}{l}\text { [powyższe oraz] } \\
\text { zdolność } \\
\text { analizy dużych } \\
\text { zbiorów danych }\end{array}$ & $\begin{array}{l}\text { wydzielone jednostki } \\
\text { o elastycznych for- } \\
\text { mach organizacyj- } \\
\text { nych, internaliza- } \\
\text { cja IT i analityczne } \\
\text { obszary funkcjonalne }\end{array}$ & $\begin{array}{c}\text { [powyższe oraz] } \\
\text { dywersyfikacja } \\
\text { platform }\end{array}$ & $\begin{array}{l}\text { nowy model kosz- } \\
\text { tów i przycho- } \\
\text { dów: rekonfigura- } \\
\text { cja aktywów w celu } \\
\text { opracowania nowych } \\
\text { modeli biznesowych }\end{array}$ \\
\hline
\end{tabular}

Źródło: opracowanie własne na podstawie Verhoef i in., 2021.

Transformacja cyfrowa jest szczególnie istotna dla firm zasiedziałych (Burnet-Wyrwa, 2018). Przedsiębiorstwa zasiedziałe muszą stawić czoła wyzwaniom i barierom podczas wyszukiwania i wdrażania innowacji w modelach biznesowych na potrzeby transformacji cyfrowej. Często są zmuszone do rozwiązywania konfliktów między istniejącymi a nowymi sposobami prowadzenia biznesu (Christensen, Bartman, Bever, 2016; Markides, 2006). Przejście na cyfryzację może często wymagać wyraźnego odejścia od status quo i także prowadzić do dezaktualizacji istniejących modeli biznesowych (Teece, 2010). Podmioty zasiedziałe mogą zacząć od drobnych zmian (np. cyfryzacji lub ucyfrowienia), aby stopniowo całkowicie przekształcić swój tradycyjny model biznesowy. Przykładem mogą być przedsiębiorstwa motoryzacyjne, które, zapewniając dostęp do mediów cyfrowych i oferując ulepszone funkcje bezpieczeństwa za pomocą czujników wykrywających aktywność w martwych punktach, aby uniknąć wypadków, poprawiają doświadczenia swoich klientów, co z kolei może przyspieszyć projekty cyfrowe, takie jak autonomiczna jazda (Svahn, Mathiassen, Lindgren, 2017).

2. Wymiary transformacji cyfrowej w kontekście tworzenia i przechwytywania wartości dodanej

Przedsiębiorstwa często ulegają iluzji, że samo wykorzystanie technologii cyfrowych jest już formą transformacji cyfrowej. Jednak mogą być to tylko doraźne zmiany oraz inwestycje w nowe technologie cyfrowe, które nie przynoszą efektywnych wyników. W związku z tym Mohan Subramaniam (2021) 
wyodrębnia cztery wymiary transformacji cyfrowej, mające różne cele strategiczne, umożliwiające firmom w odrębny sposób maksymalizowanie wartości dodanej, którą generują za pomocą technologii cyfrowych. Odróżnienie tych wymiarów ma na celu ukierunkowanie opracowania strategii cyfrowej transformacji, pozwalającej pełniej zastosować technologie cyfrowe do wykorzystania wartości dodanej. Wymaga to z kolei kompleksowej oceny tego, co mogą zaoferować technologie cyfrowe. Każdy z wymienionych wymiarów jest zilustrowany przykładem, pokazującym strategiczne korzyści dostępne w poszczególnych wymiarach transformacji cyfrowej.

Pierwszy z wyróżnionych wymiarów dotyczy zwiększenia wydajności operacyjnej dzięki wykorzystaniu i przetworzeniu danych w obrębie przedsiębiorstwa w czasie rzeczywistym do natychmiastowych korekt w procesie produkcyjnym. Na przykład w zakładach Forda wprowadzono nową zautomatyzowaną wizualną inspekcję prac lakierniczych, wykorzystując w tym celu rozszerzoną i wirtualną rzeczywistość, IoT i sztuczną inteligencję. Korzystając z tych technologii, firma usprawnia wykrywanie skaz i ogranicza usterki w swoich samochodach. W tym przypadku dane są generowane przez nowe technologie z wykorzystaniem zasobów w zakładach produkcyjnych, a sztuczna inteligencja wykorzystuje te dane do wykrywania i zapobiegania defektom produkcyjnym w czasie rzeczywistym.

Drugi wymiar to zaawansowana wydajność operacyjna, która wykorzystuje dane generowane przez użytkowników. Na przykład Caterpillar instaluje czujniki w produkowanych przez siebie maszynach budowlanych, aby śledzić, jak każda $\mathrm{z}$ nich jest eksploatowana podczas prowadzenia prac budowlanych. Pozwala to m.in. na bardziej adekwatną ocenę zapotrzebowania klientów, co jest następnie wykorzystywane w procesie projektowania nowych rodzajów urządzeń. Zasadnicza różnica z pierwszym wymiarem polega na tym, że dane z czujników w produktach firmy są generowane przez działania klientów korzystających z tych produktów, a nie ograniczają się do generowania w oparciu o zasoby własne zakładu produkcyjnego.

Wymiar trzeci obejmuje usługi bazujące na danych pochodzących z łańcuchów wartości. Przykładem jest nowy rodzaj usługi oferowanej przez firmę GE. Analizuje ona dane z czujników zamontowanych w silnikach odrzutowych, korzystając ze sztucznej inteligencji, i w czasie rzeczywistym przekazuje pilotom wskazówki, w jaki sposób zoptymalizować zużycie paliwa. Następnie GE przywłaszcza część oszczędności kosztów swoich klientów poprzez nowe opłaty od przychodów „opartych na wynikach". W tym przypadku dochodzi do zmiany dominującego modelu biznesowego $\mathrm{z}$ takiego, który jest ukierunkowany na wytwarzanie i sprzedaż produktów, na taki, który klientom zapewnia usługi oparte na danych cyfrowych. Jednostki badawczo-rozwojowe, rozwój produktów, sprzedaż i serwis posprzedażny firmy GE są zintegrowane cyfrowo, aby odbierać, analizować, generować, udostępniać i reagować 
na dane z czujników i danych IoT z tysięcy oddzielnych produktów w czasie rzeczywistym. Prowadzi to do nowych strumieni przychodów, a nie tylko do zwiększenia wydajności operacyjnej.

Poziom czwarty obejmuje usługi oparte na danych z platform cyfrowych (Gawer, Srnicek, 2021). Jako przykład można wskazać firmę Peloton wykorzystującą dane z czujników produktu ze swojego sprzętu do ćwiczeń, aby stworzyć społeczność użytkowników i dopasować poszczególnych klientów do odpowiednich urządzeń. Produkty tej firmy generują dane dotyczące interakcji użytkowników, którymi posługuje się ona do ułatwiania wymiany między swoimi cyfrowymi klientami a różnymi podmiotami zewnętrznymi spoza sfery jej łańcuchów wartości. Algorytmy sztucznej inteligencji dopasowują konkretnych użytkowników do odpowiednich urządzeń na podstawie analizy danych dotyczących interakcji produktu z użytkownikiem. Podobnie jak GE w poprzednim przykładzie, Peloton generuje nowe przychody ze swoich usług opartych na danych, ale osiagga to poprzez rozszerzanie swoich produktów na platformy cyfrowe. Ten poziom transformacji cyfrowej jest największym wyzwaniem dla firm działających w epoce przemysłowej, a także dla firm funkcjonujących na bazie modeli biznesowych opartych na łańcuchu wartości i mających niewielkie doświadczenie z platformami cyfrowymi. Warto podkreślić, że nowoczesne technologie cyfrowe mają dwa znaczące nośniki wartości: dane w ich nowej ekspansywnej roli oraz wyłaniające się ekosystemy cyfrowe (to pojęcie jest bliżej określone w dalszej części tekstu).

Kiedyś dane były epizodyczne (generowane przez dyskretne zdarzenia, takie jak wysyłka komponentu od dostawcy), ale coraz częściej stają się interaktywne (generowane w sposób ciągły przez czujniki i IoT w celu śledzenia informacji). To ciągłe śledzenie zasobów i ich parametrów operacyjnych może zwiększyć produktywność. Używając czujników do śledzenia i utrzymywania poziomów temperatury podczas przegrzewania roztopionej stali, można poprawić jakość i wydajność. Umieszczając czujniki w niektórych produktach, można zrewolucjonizować doświadczenia użytkownika, np. inteligentne materace śledzące tętno użytkowników, wzorce oddychania i ruchy ciała, a następnie dostosowujące swój kształt w czasie rzeczywistym, aby poprawić jakość snu użytkowników.

Tego rodzaju interaktywność odwraca role produktów i danych. Dane tradycyjnie wspierały produkty, ale obecnie coraz częściej to dane wpływają na sposób wykorzystania produktów. Produkty nie tylko dostarczają funkcjonalności, pomagają budować markę lub generować przychody - teraz służą również jako kanały dla interaktywnych danych i źródła dla nowych doświadczeń klientów. Aby wykorzystać nową rolę interaktywnych danych, firmy potrzebują również sieci generatorów i odbiorców danych. Takie sieci mogą wywodzić się z łączności wykorzystującej czujniki i IoT, które stanowią ekosystemy cyfrowe. 
Pojawiły się dwa główne rodzaje ekosystemów cyfrowych, z których żaden nie istniał przed nowoczesnymi postępami w zakresie danych i łączności cyfrowej. Jednym z nich jest ekosystem produkcyjny, który obejmuje powiązania cyfrowe w ramach łańcuchów wartości. Łącząc np. dane z czujników i IoT z samochodów z dostawcami części zamiennych, magazynami i dealerami serwisowymi, firmy samochodowe mogą oferować usługi konserwacji predykcyjnej. Drugi rodzaj to ekosystem konsumpcji, który obejmuje sieci poza łańcuchem wartości firmy. Jako przykład można wskazać inteligentne żarówki na lampach ulicznych, które są zaprojektowane do wykrywania strzałów $\mathrm{z}$ broni: ich ekosystemy konsumenckie obejmują m.in. sieć kamer oraz operatorów linii alarmowych, które łącznie pomagają poprawić bezpieczeństwo na ulicy. Zarówno ekosystemy produkcyjne, jak i konsumpcyjne, zasilane interaktywnymi danymi, tworzą nową wartość. Jak pokazuje rysunek 2, dotyczy to czterech poziomów cyfrowej transformacji omówionych powyżej. Pierwsze trzy poziomy opierają się na ekosystemach produkcyjnych, a czwarty na ekosystemach konsumpcyjnych.

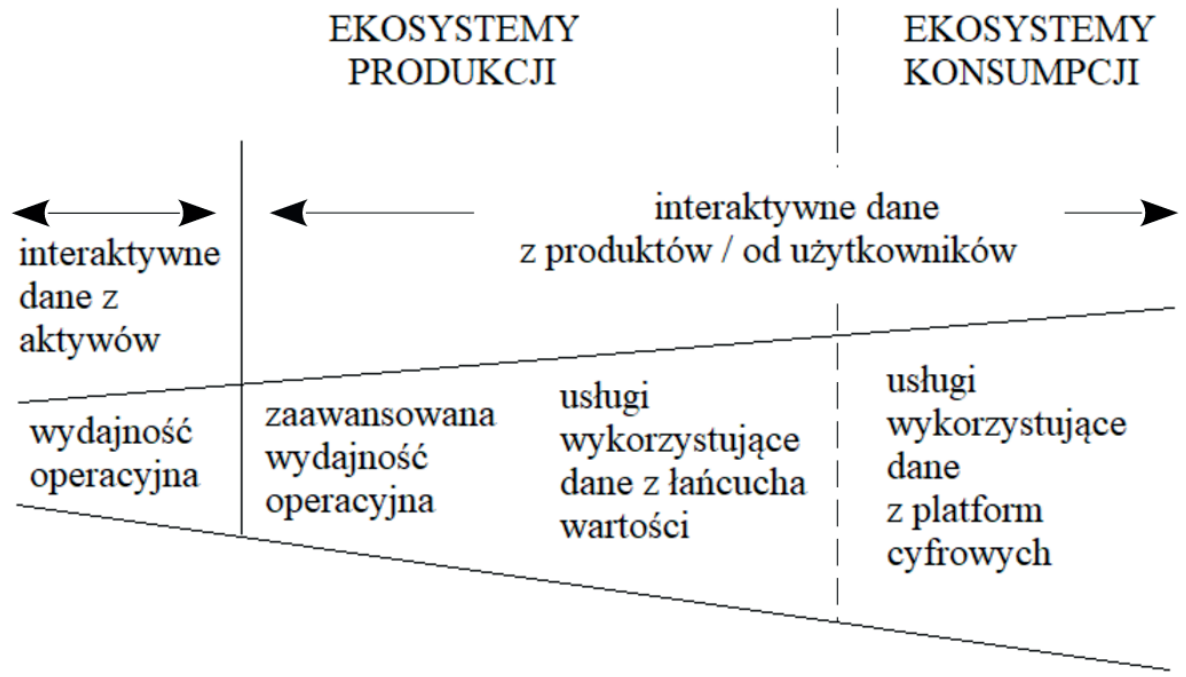

Rysunek 2. Wymiary transformacji cyfrowej

Źródło: opracowanie własne na podstawie Subramaniam, 2021

Aby określić optymalną strategię transformacji cyfrowej przedsiębiorstwa, należy ocenić potrzebę zaangażowania się na każdym z czterech poziomów przedstawionych na rysunku 2, a następnie skoncentrować się na inwestycjach, które 
pomogą przedsiębiorstwu wykorzystać zalety interaktywnych danych i ekosystemów cyfrowych. Poziom pierwszy jest koniecznością, ponieważ przeważający odsetek firm może czerpać korzyści z wydajności operacyjnej. Zdecydowana większość inicjatyw transformacji cyfrowej odbywa się na tym poziomie, co jest szczególnie ważne, jeśli wydajność operacyjna pełni istotną rolę w strategii przedsiębiorstwa. Na przykład, jeśli firmy naftowe i gazowe, które inwestują duże nakłady w szyby naftowe, rurociągi i rafinerie, decydują się na wykorzystanie urządzeń IoT i sztucznej inteligencji do znajdowania zasobów naturalnych oraz utrzymania rurociągów i aktywów rafineryjnych, mogą zaoszczędzić do $60 \%$ kosztów operacyjnych. Kluczowe wyzwania na tym poziomie obejmują zainstalowanie szeroko zakrojonego interaktywnego generowania danych w zakresie wykorzystania zasobów i przełamywanie wewnętrznych silosów organizacyjnych, blokujących udostępnianie danych.

Poziom drugi jest niezbędny dla firm sprzedających produkty, mające potencjał pozyskiwania interaktywnych danych od użytkowników, które można wykorzystać do uzyskania dodatkowej strategicznej przewagi oprócz tego, co jest dostępne na poziomie pierwszym. Trudno natomiast wyjść poza poziom drugi, jeśli interaktywne dane użytkownika produktu nie są dostępne w odniesieniu do usług generujących przychody. Wiele towarów sprzedawanych detalicznie w opakowaniach należy do tej kategorii. $\mathrm{W}$ takich firmach podstawowym zastosowaniem interaktywnych danych jest poprawa wydajności reklamy lub procesu rozwoju produktu.

Poziom trzeci mogą wykorzystać przedsiębiorstwa, które są w stanie generować usługi bazujące na danych pochodzących z produktów i łańcuchów wartości. Takie firmy muszą wzbogacać swoje ekosystemy produkcyjne, aby rozszerzyć swoją strategiczną przewagę z wymiaru wydajności operacyjnej na wymiar nowych usług oparty na danych. Na tym poziomie firmy pokonują ważną barierę: zamiast wykorzystywać dane tylko do celów operacyjnych, wykorzystują je do generowania przychodów.

Ten etap mogą przekroczyć przedsiębiorstwa, które mają dostęp do ekosystemu konsumpcji. Na przykład zmywarki wyposażone w czujniki i sztuczną inteligencję mogą przewidywać awarie komponentów, aby oferować usługi predykcyjne, ale trudno je połączyć cyfrowo z obiektami komplementarnymi i rozbudować do postaci platform cyfrowych. Poziom czwarty jest więc strategicznie istotny dla każdej firmy, której produkty związane są z ekosystemami konsumpcji.

Oczywiście nie każda firma będzie chciała lub będzie w stanie zaangażować się w transformacje na wszystkich czterech poziomach. Niektóre mogą skupić się tylko na jednej lub kilku z nich, ale ważna jest świadomość pełnego zakresu nowych możliwości, by tworzyć przemyślaną strategię cyfrowej transformacji. 
3. Model czerpania korzyści z innowacji w odniesieniu do transformacji cyfrowej

Do czasu wprowadzenia przez Teece’a (1986) modelu czerpania korzyści z innowacji przechwytywanie wartości było często uważane za kwestię strategii cenowej nowych produktów i usług. Jest to czynnik, który należy uwzględnić, ale - zgodnie z modelem Teece'a - przechwytywanie wartości zależy od bardziej fundamentalnych czynników. Podstawowe zmienne niezależne w tym modelu to siła reżimu ochrony własności intelektualnej, aktywa komplementarne, technologie komplementarne, standardy (w tym wzorzec przemysłowy produktu) oraz czas. Mimo zmian zachowują one aktualność w świecie, w którym firmy coraz częściej oferują platformy mogące zwiększać wartość dzięki generowaniu własnych innowacji. Dodatkowymi elementami najnowszej wersji tego modelu (Teece, 2018) są więc przede wszystkim platformy cyfrowe oraz bardziej kompleksowe całości, jakie stanowią ekosystemy. Te pojęcia zostaną zdefiniowane w dalszej części artykułu.

Od czasu powstania pierwszej wersji modelu Teece’a oraz jego uaktualnień doszło do istotnych zmian w wykorzystaniu technologii cyfrowych przez przedsiębiorstwa, np. internet nie jest już narzędziem, z którego użytkownicy nie korzystają wyłącznie poprzez komputery osobiste. Jest on coraz bardziej wszechobecny, interaktywnie dostępny dla użytkowników w podróży i rozszerzany na terminale wyposażone w czujniki w dowolnym miejscu i czasie. Środki komunikacji również ewoluowały - od telefonu i poczty e-mail po aplikacje do przesyłania wiadomości, które służą również jako portale do zakupów i wielu innych usług.

Jedną z zalet modelu Teece’a było wyjaśnienie kwestii, dlaczego wysoce kreatywne, pionierskie firmy często nie potrafią przechwycić większości ekonomicznych zwrotów z innowacji. Na przykład iPod firmy Apple nie był pierwszym odtwarzaczem MP3, ale dominuje $\mathrm{w}$ tej kategorii od ponad dekady. Merck był pionierem $\mathrm{w}$ dziedzinie leków obniżających poziom cholesterolu (Zocor), ale to Pfizer, który wszedł na rynek później, zapewnił sobie lepszą pozycję rynkową dzięki Lipitorowi. Nie są to przykłady schumpeterowskich efektów twórczej destrukcji, gdyż dotyczą głównie ulepszeń stopniowych, imitacyjnych, a nie radykalnych przełomów związanych z technologiami wspomagającymi (ang. enabling technology) i ogólnego przeznaczenia (ang. general purpose technology). Model Teece’a wyjaśnia również, dlaczego niektórzy innowatorzy wygrywają na rynku, podczas gdy inni przegrywają - często z technologicznie słabszymi naśladowcami. Wyjaśnia on również, dlaczego gdy innowator „wygrywa” (tj. bierze największą część dostępnych prywatnych zysków), efekty rozlewania się (ang. spillover effects) i eksternalności są nadal znaczne (Griliches, 1992; Mansfield i in., 1977), np. społeczna stopa zwrotu z prywatnych badań i rozwoju była zwykle około 2-krotnie wyższa niż prywatna stopa zwrotu (Hall, Mairesse, Mohnen, 2010). Podstawowym imperatywem czerpania korzyści z innowacji jest to, 
że o ile wynalazca czy innowator nie wejdzie na ścieżkę doskonalenia i nie będzie miał silnej ochrony przed imitacją lub silnej ochrony własności intelektualnej, o tyle jego potencjalne przyszłe strumienie dochodów są zagrożone przejęciem przez inne podmioty.

Dla zrozumienia roli platform cyfrowych oraz ekosystemów kluczowe jest pojęcie technologii ogólnego przeznaczenia (ang. general purpose technologies - GPT), którą charakteryzują trzy cechy (Bresnahan, Jones, 2012; Bresnahan, Trajtenberg, 1995). GPT (1) są wszechobecne, tj. są w powszechnym użyciu, (2) są zdolne do ciągłego ulepszania pod względem technicznym, (3) wspomagają tworzenie innowacji komplementarnych w różnych obszarach zastosowań. Innymi słowy - GPT mają wpływ na całą gospodarkę, z czasem stają się jeszcze lepsze i generują inne innowacje, ponieważ wynalazki w jednym obszarze stymulują dokonywanie odkryć i stwarzają nowe możliwości w innych obszarach. Na przykład pierwszy dostępny na rynku mikroprocesor został opracowany przez firmę Intel w celu zmniejszenia liczby komponentów w japońskim kalkulatorze biurkowym. GPT może być produktem, procesem lub systemem organizacyjnym. Przykłady GPT, które uznaje się (Lipsey, Bekar, Carlaw, 1998) za oczywiste, na ogół ograniczają się do druku, brązu, koła wodnego, energii parowej, elektryczności, silnika spalinowego, kolei, pojazdów silnikowych, laserów i internetu. Powszechne stosowanie GPT często wymaga dekady lub więcej, aby stało się ono oczywiste, ale z czasem skumulowane skutki mogą być znaczące, jak choćby w przykładzie laserów, będących dziś w powszechnym użyciu w bardzo wielu branżach.

Wymogi stawiane GPT są duże, ale istnieje podobna kategoria, a mianowicie technologie wspomagające, które można uznać za młodszą odmianę GPT, gdyż spełniają tylko kryteria (2) i (3), gdyż niekoniecznie mają wymierny wpływ na całą gospodarkę. Chociaż lista GPT jest stosunkowo krótka, istnieją bardzo liczne przykłady technologii wspomagających. Chociaż nie zostaną uznane za „radykalne" przez historyków gospodarki badających wzrost gospodarczy, niemniej jednak są one ważne dla poszczególnych firm i branż. Często mogą zakłócać status quo i generować bardzo znaczne korzyści gospodarcze i nadwyżkę społeczną. Na przykład Komisja Europejska zidentyfikowała sześć „kluczowych technologii wspomagających" poza obszarem badań nad oprogramowaniem: mikro- i nanoelektronika, nanotechnologia, biotechnologia przemysłowa, zaawansowane materiały, fotonika i zaawansowane metody produkcji. Mogą one stanowić podstawę innowacji w produktach w wielu gałęziach przemysłu i są uznawane za kluczowe dla sprostania wyzwaniom społecznym.

Rola technologii GPT w gospodarce jest bardzo istotna, a pionierzy zazwyczaj potrafią przechwycić tylko niewielki ułamek tworzonej przez siebie wartości. 
Oznacza to, że prywatne przedsiębiorstwa będą miały tendencję do niedoinwestowania w ich tworzenie, przy braku lepszych strategii lub wsparcia rządowego. Kluczową implikacją jest to, że firmy, które wymyślają lub ulepszają GPT, mają duże trudności z przywłaszczeniem wartości wytworzonej przez swoją inwestycję. W rezultacie niedoinwestowanie w GPT i technologie wspomagające jest powszechnie obserwowanym zjawiskiem. Przechwycenie wartości z technologii prorozwojowych jest trudniejsze niż w przypadku skromnej, dyskretnej innowacji. Jeśli innowator musi polegać na partnerach w zakresie komercjalizacji technologii, zyski z innowacji musiałyby zostać podzielone, co najprawdopodobniej obniżyłoby w rezultacie zwrot. Tak jest zasadniczo w przypadku technologii wspomagających i GPT.

Złożoność i współzależność technologii komunikacyjnych leżących u podstaw rewolucji danych mobilnych spowodowały pojawienie się wielu połączonych technologii, co w efekcie doprowadziło do ukształtowania się ekosystemów biznesowych. Wyspecjalizowane firmy nie są już wyspami połączonymi z innymi tylko poprzez transakcje rynkowe. Każda z nich jest teraz częścią jednej lub więcej konstelacji podmiotów gospodarczych i organizacji, których losy są powiązane technologicznie lub konkurencyjnie. Ekosystemy powstały dla szeregu nowych usług, w tym mediów strumieniowych, przetwarzania w chmurze, IoT i systemów płatności mobilnych. Każdy z tych obszarów opiera się na komunikacji mobilnej, co umożliwia współpracę części systemu i zwiększa jego dostępność dla użytkowników końcowych. W niektórych przypadkach technologie specyficzne dla określonej funkcji są na wczesnym etapie uwzględniane w standardzie sieci bezprzewodowej. Wymaga to, aby firmy rozważające wprowadzenie dużych nowych usług zawierały sojusze i uczestniczyły w opracowywaniu standardów. Ale każda generacja standardu bezprzewodowego służy również jako technologia wspomagająca usługi, które jeszcze nie zostały opracowane. Losy ekosystemów będą się różnić w zależności od zakresu tworzenia odpowiednich komplementarności, charakteru komplementarności i sukcesu wysiłków lidera ekosystemu w zakresie koordynacji i strategii. W ekosystemach wartość przechwycona przez poszczególne firmy będzie zależeć od dynamicznych zdolności na poziomie firmy, niedoboru zasobów firmy, charakteru komplementarności i przyjętych przez nie modeli biznesowych. Dobrze funkcjonujący ekosystem pozwala na wiele sposobów osiągania zysków. Na przykład w swoim ekosystemie Google czerpie spore zyski z reklam powiązanych z wyszukiwaniami użytkowników. Z kolei w swoim ekosystemie Apple czerpie zyski ze sprzedaży atrakcyjnych i łatwych w obsłudze urządzeń oraz z udziału w przychodach $\mathrm{z}$ aplikacji i treści sprzedawanych przez ich dostawców. 


\section{Charakterystyka dojrzałej fazy transformacji cyfrowej}

Model Teece’a był kilkukrotnie modyfikowany na przestrzeni kolejnych dekad, a w 2018 roku zaprezentowana została jego wersja, która dotyczy transformacji cyfrowej (Teece, 2018). Zwrócono uwagę, że oprócz dotychczasowych czynników obecnie konieczne jest dogłębne zrozumienie dystrybucji zysków w łańcuchu wartości, co z kolei wymaga zbadania platform cyfrowych i ekosystemów, które z natury wiążą się z różnymi rodzajami komplementarności. Platforma to dowolna kombinacja sprzętu i oprogramowania, która zapewnia standardy, interfejsy i zasady umożliwiające i pozwalające dostawcom produktów komplementarnych na dodawanie wartości i interakcję ze sobą lub użytkownikami. Z kolei Michael G. Jacobides, Carmelo Cennamo i Annabelle Gawer (2018) definiują ekosystem jako grupy firm, które muszą radzić sobie z unikalnymi lub supermodułowymi komplementarnościami, które nie są ogólne, wymagają stworzenia określonych struktur relacji i dostosowania w celu stworzenia wartości.

Komplementarność jest istotą platform, a platformy pomagają tworzyć ekosystemy. Ze względu na postęp i dyfuzję technologii cyfrowych platformy stają się wszechobecne. Platformy cyfrowe wykorzystują wspólne standardy do integracji produktów i usług oraz firm przy użyciu internetu lub sieci prywatnych. Zintegrowane platformy cyfrowe dotyczą wielu funkcji biznesowych i umożliwiają tworzenie ekosystemów biznesowych. Chociaż można rozpoznać różne typy platform (Gawer, 2014), istnieje jednak znaczna niejasność co do tego, co stanowi platformę lub ekosystem. Komplementarności są wszechobecne w całym systemie gospodarczym, a zwłaszcza w rozwoju technologii i transformacji biznesowej. Mogą istnieć różne uzupełniające się aktywa, które stają się istotne w różnych momentach czasu. Zyski są generowane nie tylko z eksploatowania wąskich gardeł, gdyż wynikają również z łączenia różnych technologii w unikalne, zwiększające wartość sposoby, które prowadzą do ogólnosystemowych korzyści. W większości przypadków należy jednak uznać, że komplementarność technologiczna i innowacyjna narzuca poważne wyzwania związane z koordynacją, projektowaniem rynku i kontrolą, które utrudniają dostosowanie działań firm w gospodarce rynkowej. Weźmy przykładowo przemysł samochodowy. Od dziesięcioleci wykorzystuje on „platformy”, choć pierwotnie miały one inny charakter. „Platforma” była (i do pewnego stopnia pozostaje) wspólnym zbiorem różnych projektów, części i wysiłków produkcyjnych zorganizowanych wokół kilku różnych modeli. Ich wykorzystanie zainicjował General Motors w latach 60. ubiegłego wieku, kiedy używał tej samej platformy (podwozia) do produkcji różnych modeli: Buicka Skylarka, Chevy Chevelle, Pontiaca Le Mansa i Oldsmobile Cutlass. Podejście platformowe obniża koszty, zmniejszając potrzebę 
projektowania części, które są funkcjonalnie identyczne, ale różnią się w każdym modelu. Obecnie platformy przemysłu motoryzacyjnego przekształciły się w ekosystemy. Producenci samochodów coraz częściej funkcjonują jako integratorzy systemów, podobnie jak przemysł lotniczy.

$\mathrm{W}$ świecie cyfrowym platformy mogą być oparte wyłącznie na oprogramowaniu, jak system operacyjny Android (OS) firmy Alphabet, lub mogą być połączone ze sprzętem, iPhone i iPad firmy Apple, które są ściśle zintegrowane z zastrzeżonym oprogramowaniem Apple iOS. Platformy mogą mieć bezpośredni wpływ na konsumentów, jak w przypadku technologii smartfonów, lub mogą być bardziej ukryte, jak oprogramowanie, którego firma produkcyjna używa do koordynowania i monitorowania swoich dostawców. Tak czy inaczej platformy w świecie ICT są bardziej atrakcyjne, gdy pozwalają użytkownikom na korzystanie z bogatej gamy uzupełnień i dodatków, tj. gdy mają silne efekty networkingowe. Rozważmy przykładowo ekosystem iOS (Apple). Firma Apple w dużej mierze „rozwiązała” problem koordynacji, integrując większość elementów łańcucha wartości, które charakteryzują się dużą innowacyjnością. Sprzedaż aplikacji w jej sklepie z aplikacjami i muzyki w sklepie iTunes wspomaga komplementarność. Przychody Apple’a z generowania nowych treści stale zyskują na znaczeniu, a firma ujawnia teraz przychody z usług (głównie ze sprzedaży aplikacji) w swoich publicznych sprawozdaniach finansowych. W pierwszym kwartale 2016 roku wartość usług wyniosła 5,99 mld dolarów, prawie $12 \%$ całkowitych przychodów, co czyni go drugim co do wielkości segmentem po (znacznie większym) iPhonie i nieco większym niż przychody ze sprzedaży komputerów Mac (Teece, 2018).

Pomocne jest odróżnienie dwóch podstawowych typów platform cyfrowych z licznymi ich kombinacjami hybrydowymi. Platforma transakcyjna ułatwia wymianę pomiędzy podzielonymi w inny sposób grupami konsumentów lub firm. Paradygmatem jest tutaj eBay, który pozwala ogromnej liczbie indywidualnych sprzedawców i kupujących zlokalizowanych w dowolnym miejscu na świecie znaleźć się nawzajem z niewyobrażalną wcześniej łatwością. Chociaż cyfryzacja umożliwiła platformy transakcyjne w coraz większej liczbie branż, ten rodzaj platformy transakcyjnej nie jest całkowicie nowy. Na przykład branża kart kredytowych od dawna zapewnia realną opcję płatności, którą akceptują sprzedawcy, do której banki dołączą, wydając karty i przetwarzając transakcje, a posiadacze kart uznają wartość. Platforma innowacji zapewnia podstawową technologię i system dystrybucji, do którego inne firmy mogą dodawać własne innowacje, zwiększając wartość systemu jako całości. Ekosystem „aplikacji” Apple’a jest tego paradygmatycznym przykładem. Platformy innowacji wyraźnie pokazują potrzebę komplementarności. Może być to mniej zauważalne w przypadku platform transakcyjnych, ale wyraźniej wskazują na nią udane przykłady, takie jak platforma stworzona przez firmę Amazon. 
Poprzez przyciąganie podmiotów transakcyjnych, np. sprzedawców Amazon Marketplace, w podobny sposób, w jaki muszą przyciągać kluczowych partnerów, jest ona wystarczająco atrakcyjna, gdyż dzięki niej uczestnicy tej platformy mogą dotrzeć do masy krytycznej kupujących i sprzedających. Zasadniczo platforma cyfrowa stanowi centrum, wokół którego firmy i użytkownicy mogą wspólnie lub osobno wprowadzać innowacje i przyciągać użytkowników o wiele bardziej produktywnie, niż gdyby próbowali osiągnąć te same cele w przypadku braku platformy. Posiadanie lub kontrolowanie odnoszącej sukcesy platformy, na bazie której inne firmy budują swój model biznesowy, może zapewnić pozycję lidera, a przez to wzmocnić ekosystem i czerpać z niego wartość. Ramy teoretyczne zdolności dynamicznych pomagają wyjaśnić, dlaczego niektóre firmy z powodzeniem tworzą ekosystemy oparte na platformach, które łączą wiele modeli biznesowych. Takim firmom, jak Amazon, Apple, Facebook, Google i Microsoft udało się wyczuć szanse rynkowe poza obszarem ich pierwotnej działalności, wykorzystać je, mobilizując odpowiednie zasoby i, co najważniejsze, przekształcając swoje organizacje poprzez dodanie możliwości, jaką stanowią platformy, w szczególności do zarządzania komplementarnościami w ekosystemie.

Liderzy platform biorą odpowiedzialność za kierowanie ciągłą ewolucją technologiczną systemu. Tworzenie i przechwytywanie wartości wymaga połączenia otwartości (aby przyciągnąć komplementariuszy) i pewnego stopnia kontroli (aby budować dobre doświadczenia u użytkownika). Po utworzeniu platformy mogą pojawić się możliwości przechwycenia wartości poprzez sprzedaż urządzeń i inne mechanizmy. Gdy istnieje konkurencja między platformami, adopcja i sukces komercyjny są prawdopodobnie funkcją tego, kto może zrekrutować najwięcej (i najlepszych) komplementariuszy. $Z$ biegiem czasu przewaga należy do liderów platform ustalających zasady w sposób, który najprawdopodobniej przyniesie korzyści całemu systemowi, a nie tylko własnym krótkoterminowym interesom.

W ekosystemach opartych na platformach konkurencja występuje na trzech poziomach: (1) między jedną platformą a drugą, jak to miało miejsce w przypadku VHS kontra Betamax w walce o rynek magnetowidów czy obecny przypadek Apple iOS kontra Google Android w sektorze urządzeń mobilnych; (2) między platformą a jej partnerami, czego przykład stanowi przechwytywanie przez firmę Microsoft części wartości z przeglądarek, multimediów strumieniowych i aplikacji do obsługi wiadomości błyskawicznych, które działały w jej systemie operacyjnym Windows; (3) między komplementariuszami, z których każda szuka pozycji w ekosystemie opartym na platformach, jak w przypadku dwóch gier mobilnych, z których każda rywalizuje o ten sam segment konsumencki.

Mimo tej złożoności można sformułować kilka uogólnień dotyczących platform. Po pierwsze, konkurencja między platformami ma tendencję do generowania 
wyników typu „Zwycięzca bierze wszystko”, gdy występują duże oszczędności skali po stronie popytu lub podaży i brak korzyści z niszowej specjalizacji. Konkurencja między platformami prowadzi również do otwartości, która wynika $\mathrm{z}$ tego, że każda platforma stara się rekrutować więcej programistów; im większa otwartość, tym mniejsza szansa dla dostawcy na bezpośrednie uchwycenie wartości. Dobrą strategią przechwytywania wartości jest pozyskiwanie znanych marek/partnerów, którzy mogą sprowadzać na platformę duże grupy klientów (Cusumano, Gawer, 2002).

W przypadku platform wielopoziomowych zarządzanie rywalizacją między partnerami z platformy i między partnerami wymaga zachowania równowagi pomiędzy współpracą a rywalizacją. W analizie modelu czerpania zysku z innowacji podstawowe pytanie brzmi: czy istnieje prawdopodobieństwo wystąpienia wąskiego gardła konkurencyjnego? Jeśli tak, to gdzie i kiedy stanie się to oczywiste, jeśli obecnie tak nie jest? Wnikliwa identyfikacja przyszłego wąskiego gardła jest potencjalną okazją do zbudowania lub zakupu niezbędnych zasobów, aby z niego skorzystać (lub nie ucierpieć z powodu jego braku). Wymaga to silnych zdolności dynamicznych, w tym umiejętności organizacyjnych w wykrywaniu i przechwytywaniu tych zasobów.

5. Geneza szybkiego rozwoju platform cyfrowych

Niemal wszechobecną cechą firm cyfrowych, a zwłaszcza platform cyfrowych, jest ich imponujący wzrost. Na przykład liczba wyszukiwań Google wzrosła z 1 mld rocznie w 1999 roku do 2,7 bln w 2020 roku, co oznacza wzrost o 50\% rocznie w okresie 20 lat. Podobnie liczba aktywnych użytkowników Facebooka rosła o około 25\% rocznie w latach 2009-2020 (na podstawie danych Statista).

Chociaż do tych imponujących liczb mogło przyczynić się wiele czynników, dwa kluczowe, które stoją za takim wzrostem, to wysoka skalowalność platformy i wzmacnianie efektów networkingu. Platformy mogą szybko rosnąć i obsługiwać coraz większą liczbę użytkowników, w tym klientów, dostawców, dostawców usług komplementarnych, ponieważ koszty obsługi dodatkowych użytkowników są niskie, a w przypadku platform cyfrowych czasem znikome. Następnie model platformy sugeruje, że wzrost liczby jej użytkowników (np. klientów lub dostawców) przyciąga konsumentów (użytkowników końcowych), gdyż uzyskują oni wyższą użyteczność z korzystania z platformy ze względu na nasilające się efekty networkingu, które tworzą sprzężenie zwrotne (Eisenmann, Parker, Van Alstyne, 2006). Aby zilustrować siłę modelu biznesowego opartego na platformie, w tabeli 3 przedstawiono statystyki wyników finansowych wybranego przedsiębiorstwa platformowego 
i nieplatformowego. Firmy platformowe osiągają znacznie wyższy dochód netto i kapitał własny na pracownika niż firmy nieplatformowe: ponad 38-krotnie większy dochód netto na pracownika (tabela 3).

Tabela 3. Porównanie przedsiębiorstwa platformowego i nieplatformowego

\begin{tabular}{cccc}
\hline Nazwa & Liczba pracowników & $\begin{array}{c}\text { Dochód netto } \\
\text { (mld dolarów) }\end{array}$ & $\begin{array}{c}\text { Dochód netto na } \\
\text { pracownika } \\
\text { (dolarów) }\end{array}$ \\
\hline Daimler AG & 298700 & 3,14 & 10512 \\
\hline Apple & 137000 & 55,26 & 403357 \\
\hline
\end{tabular}

Źródło: opracowanie własne na podstawie danych Statista (za 2019 rok). Pobrane z: www.statista.com (9.10.2021).

Podczas gdy rozwój platform początkowo silnie zależy od wprowadzenia udanego produktu, $\mathrm{z}$ czasem coraz bardziej istotne staje się nastawienie ukierunkowane na rozwój platformy (Zhu, Furr, 2016). Ta zmiana oznacza odejście od skupiania się na tworzeniu nowych produktów w kierunku zarządzania partnerami platformy, takimi jak dostawcy i klienci (McIntyre, Srinivasan, 2017), nawet jeśli skutkuje to niższą sprzedażą produktów (Rietveld, Eggers, 2018).

\section{Strategie rozwoju platform}

W zakresie strategii rozwoju platform wyróżnia się trzy podstawowe strategie. Pierwsze z nich to (1) penetracja rynku i (2) rozwój rynku (oparty na produktach). Platformy mogą wykorzystywać swoje cyfrowe i przełomowe technologie, aby osiągnąc znaczny wzrost poprzez przyciągnięcie do grona klientów osób niebędących użytkownikami, które nigdy wcześniej nie korzystały z produktu lub jego tradycyjnego substytutu. Na przykład około 30\% użytkowników Netflixa nie ogląda telewizji, ale przesyła strumieniowo treści za pomocą tabletów, laptopów lub telefonów komórkowych. W niektórych przypadkach może to prowadzić do stworzenia zupełnie nowych rynków. Co ważne, nie tylko firmy w fazie transformacji cyfrowej, ale także firmy w fazie ucyfrowienia mogą stosować te strategie rozwoju rynku. Przykładowo tradycyjni sprzedawcy detaliczni mogą dodać kanał online, aby przyciągnąć klientów z innych sklepów detalicznych, by zwiększyć swój udział w rynku, ale także kierować i obsługiwać nowe rynki biznesowe.

Oprócz tych bardziej tradycyjnych strategii firmy cyfrowe mogą również realizować strategię (3) polegającą na penetracji rynku opartej na platformach, 
wprowadzając na nowy rynek platformę składającą się z różnych istniejących produktów, które są oferowane przez podmioty zewnętrzne. Norweska firma telekomunikacyjna Telenor opracowała platformę składającą się z mobilnych, stacjonarnych technologii typu maszyna-maszyna, obsługujących szeroki zakres rynków w całej Europie. Podobnie firma Apple opracowała globalny ekosystem dla swoich telefonów, tabletów czy telewizorów.

$\mathrm{Z}$ uwagi na wymiar pionowy wyodrębnia się dwie strategie. Pierwsza $\mathrm{z}$ nich, jaką jest rozwój produktu, może być również stosowana przez firmy cyfrowe. Firmy cyfrowe mogą często wydajniej opracowywać i wprowadzać nowe produkty w środowisku platformy, ponieważ platformy umożliwiają silniejszą synergię między produktami. Na przykład firmy zajmujące się grami mobilnymi, takie jak Ketchapp, wykorzystują platformy do gier, aby wprowadzać na rynek stały strumień gier mobilnych przy stosunkowo niewielkich kosztach rozwoju i promocji. Druga strategia polega na opracowaniu platformy współtworzenia, która pozwala użytkownikom zewnętrznym na aktywne współtworzenie wartości poprzez nadanie im uprawnień do samodzielnego wykonywania pewnych czynności na platformie (Cui, Wu, 2016).

Istnieją stosunkowo proste formy współtworzenia, w których platformy cyfrowe pozwalają klientom angażować się w marketing szeptany lub pisać recenzje produktów (TripAdvisor, Booking), lub dzielić się innowacyjnymi pomysłami na platformach crowdsourcingowych (Dell IdeaStorm). Jednocześnie platformy mogą również umożliwiać klientom wykonywanie bardziej merytorycznych działań poprzez zmianę ról tak, aby klienci stali się dostawcami, jak na internetowych rynkach (Airbnb i eBay), lub współproducentami podczas projektowania, modyfikowania lub montażu produktów (np. komputery Dell, NikeID). Przekształcenie ról z klientów w producentów lub w dostawców to raczej przypadek przedsiębiorstw, które dokonały transformacji cyfrowej, natomiast rzadko obserwujemy te dalekosiężne strategie współtworzenia u firm we wcześniejszych fazach transformacji cyfrowej (cyfryzacja, ucyfrowienie). Niektóre firmy są w stanie połączyć wszystkie podejścia w jedną strategię, którą można określić jako dywersyfikację platformy. Ta strategia wzrostu jest często wdrażana przez duże, odnoszące sukcesy platformy mające na celu stworzenie dodatkowego wzrostu na niezbadanych rynkach za pomocą nowych produktów. Takie podejście polega na rozszerzeniu platformy w celu obsługi nowych rynków, aktualizacji asortymentu produktów i usług oraz otwarciu firmy na współtworzenie wartości poprzez współpracę ze sponsorami (Google i Android) lub innymi interoperacyjnymi platformami, dostawcami, konsumentami i dostawcami usług komplementarnych.

W końcowej części tego puntu przejdziemy do zagadnienia standardów. Określenie standardów było oczywiście istotne w przedcyfrowym świecie produkcji przemysłowej, ale wyzwania i szanse z nimi związane w tym przypadku są stosunkowo 
niewielkie w porównaniu ze światem cyfrowym. W świecie przemysłowym standardy dotyczyły tylko kompatybilności i wzorców; w świecie cyfrowym często chodzi o rozwój technologii, a także zapewnienie kompatybilności.

Standardy technologiczne dają gwarancję podstawy funkcjonowania platformy, na których konkurencyjne firmy budują swoją ofertę produktów i usług. Terminowe tworzenie i rozwijanie standardów jest ważne dla zdolności niezintegrowanych firm do oferowania stale ulepszanego sprzętu i oprogramowania. Zrozumienie standardów i opracowywania standardów jest istotne dla poznania platform cyfrowych i ekosystemów. Standardy pojawily się w pierwotnych ramach modelu Teece’a przede wszystkim w postaci dominujących wzorców przemysłowych. Dominujące wzorce przemysłowe (np. model T samochodu stworzony przez Henry'ego Forda, czy iPhone frimy Apple) pojawiają się w wyniku konkurencji rynkowej i stają się de facto standardami, w przeciwieństwie do telekomunikacji bezprzewodowej i innych rodzajów złożonych standardów, które są opracowywane wspólnie, zwykle pod auspicjami organów ustanawiających standardy, takich jak ETSI czy IEEE.

\section{Podsumowanie}

Każda z omówionych faz transformacji cyfrowej nakłada określone wymagania na zasoby cyfrowe firmy, strukturę organizacyjną, strategie rozwoju i wskaźniki. Firmy dążące do transformacji cyfrowej muszą nie tylko dysponować zasobami cyfrowymi, ale także nabywać lub rozwijać zdolności związane z elastycznością cyfrową, sieciami cyfrowymi i analizą dużych zbiorów danych. Wewnętrznie organizacje muszą rozbudowywać zwinne struktury o niskim poziomie hierarchii oraz internalizować w firmie umiejętności informatyczne i analityczne. W artykule wyróżnione zostały podstawowe strategie rozwoju dla firm, które stosują strategie oparte na platformach, a mianowicie: rozwój rynku oparty na platformie, współtworzenie klientów i dywersyfikacja platformy.

Pozostaje jednak wiele kwestii otwartych dla przyszłych badań (Verhoef i in., 2021). Zagadnienie, które nadal wymaga pełniejszego zrozumienia, to sposób, w jaki firmy przechodzą przez fazy transformacji cyfrowej. Zakłada się, że zasiedziałe firmy przechodzą przez tę samą sekwencję cyfryzacji, ucyfrowienia, a następnie pełnej i całościowej transformacji cyfrowej. Nie jest jednak jasne, czy taka ścieżka jest optymalna w przypadku wszystkich rodzajów przedsiębiorstw. Być może powinny one pominąć fazę ucyfrowienia, aby zrealizować pełną transformację cyfrową, ponieważ ta faza może utrudniać jej wprowadzenie.

Stosunkowo niewiele wiadomo też o tym, w jakim stopniu firmy powinny dokonać transformacji cyfrowej. Chociaż transformacja cyfrowa wydaje się nieunikniona 
w wielu branżach, nadal nie należy jej uważać za cel sam w sobie, biorąc pod uwagę potrzebne głębokie zmiany i wysokie ryzyko. Brak kompleksowych badań empirycznych dotyczących powiązań między różnymi fazami transformacji cyfrowej a wydajnością prowadzi do ważnego pytania: w jakim stopniu firmy powinny dokonać transformacji cyfrowej? Nadto jaki jest wpływ różnych faz transformacji cyfrowej na wydajność? Konieczne jest pełniejsze przebadanie wpływu czynników kontekstowych oraz określenie, które z rynkowych czynników wewnętrznych (np. wielkość firmy, wiek, skład zarządu) i zewnętrznych (np. intensywność konkurencji, intensywność technologiczna) mogą moderować wpływ transformacji cyfrowej na wyniki firmy. Ponadto jednym z kluczowych obszarów zainteresowania przedsiębiorców oraz polityków jest bezpieczeństwo cyfrowe, a także uwzględnienie możliwych ryzyk związanych z globalnymi zakłóceniami w funkcjonowaniu internetu oraz platform cyfrowych (Carcary, Doherty, Conway, 2019).

Ważnym tematem badań pozostają nadal zasoby cyfrowe, aby odpowiedzieć na szereg powiązanych pytań: jak można je rozwijać? Jaki jest względny wpływ każdego z nich na kształtowanie sukcesu transformacji cyfrowej? W jakie aktywa i zdolności dynamiczne firmy muszą inwestować? Czy należy skoncentrować się na pozyskiwaniu zasobów cyfrowych, rozwoju sieci cyfrowych lub możliwościach analizy dużych zbiorów danych? W jakim stopniu sprawność cyfrowa i możliwości tworzenia sieci cyfrowych pomagają tylko firmom cyfrowym, czy też możliwości te są również istotne dla firm mniej cyfrowych? W stosownych przypadkach, w jaki sposób te firmy mogą je mierzyć, rozwijać i doskonalić? Podsumowując, musimy dowiedzieć się więcej o tym, jak zasoby cyfrowe ułatwiają transformację cyfrową.

Jednym z kluczowych zagadnień jest strategia rozwoju cyfrowego. Aby uchwycić, co sprawia, że różne strategie rozwoju platformy są skuteczne lub nie, należy uwzględnić takie pytania, jak: jaka jest optymalna ścieżka rozwoju w środowisku platformy? A w przypadku, gdy platforma jest liderem rynkowym, czy powinna dywersyfikować się na inne rynki w poszukiwaniu większych efektów sieciowych, czy też powinna specjalizować się, aby pozostać konkurencyjna na istniejącym rynku? Jakie cechy firmy i rynku mogą wyjaśniać różnice w wynikach firm stosujących różne strategie oparte na platformach? Na tej podstawie, jakie strategie wzrostu powinny wybrać firmy i jak zasiedziałe firmy mogą osiągnąć podobne wskaźniki wzrostu, jak wchodzące na rynek nowe podmioty cyfrowe firmy? Chociaż operatorzy zasiedziali mogą z powodzeniem wdrażać nowe technologie cyfrowe, udane przypadki biznesowe są dość rzadkie. Ponadto, biorąc pod uwagę heterogeniczność zwrotu z inwestycji cyfrowych w produktywność, ważne jest, aby określić, które czynniki mogą wyjaśniać te różnice. 


\section{Bibliografia}

Batko, R., Baliga-Nicholson, K. (2019). Digital Innovation as the Key Factor in Changing Organizational Identity into a Digital Organizational Identity: Innowacja cyfrowa jako kluczowy czynnik przemiany tożsamości organizacyjnej w cyfrową tożsamość organizacyjną. Problemy Zarzadzania, 17(4), 39-51.

Bresnahan, T. F., Jones, B. (2012). Generality, Recombination, and Reuse. W: J. Lerner, S. Stern (red.), The Rate and Direction of Inventive Activity Revisited (s. 611662). Chicago: University of Chicago Press.

Bresnahan, T. F., Trajtenberg, M. (1995). General Purpose Technologies 'Engines of growth'? Journal of Econometrics, 65(1), 83-108.

Burnet-Wyrwa, W. (2018). Strategie transformacji cyfrowej przedsiębiorstw o zasięgu globalnym - studium przypadku. Marketing i Rynek, 12, 54-66.

Carcary, M., Doherty, E., Conway, G. (2019). A Framework for Managing Cybersecurity Effectiveness in the Digital Context. W: T. Cruz, P. Simoes (red.), Proceedings of the 18 $8^{\text {th }}$ European Conference on Cyber Warfare and Security (s. 78-86). Reading: Academic Conferences and Publishing International Limited.

Christensen, C. M., Bartman, T., Bever, D. van. (2016). The Hard Truth about Business Model Innovation. Sloan Management Review, 58(1), 30-40.

Cui, A. S., Wu, F. (2016). Utilizing Customer Knowledge in Innovation: Antecedents and Impact of Customer Involvement on New Product Performance. Journal of the Academy of Marketing Science, 44(4), 516-538.

Cusumano, M. A., Gawer, A. (2002). The Elements of Platform Leadership. MIT Sloan Management Review, 43(3), 51.

Eisenmann, T., Parker, G., Van Alstyne, M. W. (2006). Strategies for Two-Sided Markets. Harvard Business Review, 84(10), 92.

Gawer, A. (2014). Bridging Differing Perspectives on Technological Platforms: Toward an Integrative Framework. Research Policy, 43(7), 1239-1249.

Gawer, A., Srnicek, N. (2021). Online Platforms: Economic and Societal Effects. Brussels: European Parliament.

Griliches, Z. (1992). The Search for R\&D Spillovers. The Scandinavian Journal of Economics, 94, Suppl., 29-47.

Hall, B. H., Mairesse, J., Mohnen, P. (2010). Measuring the Returns to R\&D. W: B. H. Hall, N. Rosenberg (red.), Handbook of the Economics of Innovation (t. 2, s. 1033-1082). Amsterdam: North Holland.

Jabłoński, M., Jabłoński, A., Szpitter, A. (2020). Dynamika modeli biznesu przedsiębiorstw w gospodarce cyfrowej - perspektywa monetyzacji. W: S. Gregorczyk, G. Urbanek (red.), Zarzadzanie strategiczne w dobie cyfrowej gospodarki sieciowej (s. 9-15). Łódź: Wydawnictwo Uniwersytetu Łódzkiego. 
Jacobides, M. G., Cennamo, C., Gawer, A. (2018). Towards a Theory of Ecosystems. Strategic Management Journal, 39(8), 2255-2276.

Kawalec, P. (2013). Profiting from Innovation. Methodological Ramifications of Decision Factors. W: M. Pawlak (red.), Nowe tendencje w zarządzaniu - uwarunkowania społeczne (t. 4, s. 113-122). Lublin: Wydawnictwo KUL.

Kotler, P., Kartajaya, H., Setiawan, I. (2021). Marketing 5.0 Technology for Humanity. Hoboken: Wiley.

Lipsey, R. G., Bekar, C., Carlaw, K. (1998). What Requires Explanation. General Purpose Technologies and Economic Growth, 2, 15-54.

Mansfield, E., Rapoport, J., Romeo, A., Wagner, S., Beardsley, G. (1977). Social and Private Rates of Return from Industrial Innovations. The Quarterly Journal of Economics, 91(2), 221-240.

Markides, C. (2006). Disruptive Innovation: In Need of Better Theory. Journal of Product Innovation Management, 23(1), 19-25.

McIntyre, D. P., Srinivasan, A. (2017). Networks, Platforms, and Strategy: Emerging Views and Next Steps. Strategic Management Journal, 38(1), 141-160.

Parker, G., Van Alstyne, M. W., Jiang, X. (2016). Platform Ecosystems: How Developers Invert the Firm. Management Information Systems Quarterly, 41(1), 255-266.

Parviainen, P., Tihinen, M., Kääriäinen, J., Teppola, S. (2017). Tackling the Digitalization Challenge: How to Benefit from Digitalization in Practice. International Journal of Information Systems and Project Management, 5(1), 63-77.

Polska Agencja Rozwoju Przedsiębiorczości (2021). Potrzeby kompetencyjne w kontekście skutków pandemii koronawirusa. Raport zbiorczy z badania dotyczacego działan antyCOVIDowych w sektorach: Informatyka oraz Telekomunikacja i Cyberbezpieczeństwo. Pobrane z: https://www.piit.org.pl/o-nas/aktualnosci/ raport-potrzeby-kompetencyjne-w-kontekscie-skutkow-pandemii-koronawirusa (9.10.2021).

Rietveld, J., Eggers, J. P. (2018). Demand Heterogeneity in Platform Markets: Implications for Complementors. Organization Science, 29(2), 304-322.

Schallmo, D., Williams, C. A., Boardman, L. (2020). Digital Transformation of Business Models - Best Practice, Enablers, and Roadmap. Digital Disruptive Innovation, 119-138.

Sebastian, I. M., Ross, J. W., Beath, C., Mocker, M., Moloney, K. G., Fonstad, N. O. (2020). How Big Old Companies Navigate Digital Transformation. W: R. D. Galliers, D. E. Leidner, B. Simeonova (red.), Strategic Information Management (s. 133150). London: Routledge.

Smulski, J. (2020). Rynek IT i telekomunikacji w Polsce. Szanse, zagrożenia, bariery rozwoju. Raport PIIT. Pobrane z: https://www.piit.org.pl/o-nas/aktualnosci/ 
raport-piit-rynek-it-i-telekomunikacji-w-polsce-2020.-szanse,-zagrozenia,-bariery-rozwoju (9.10.2021).

Subramaniam, M. (2021). The 4 Tiers of Digital Transformation. Harvard Business Review. Pobrane z: https://hbr.org/2021/09/the-4-tiers-of-digital-transformation (9.10.2021).

Statista. Pobrane z: www. statista.com (9.10.2021).

Svahn, F., Mathiassen, L., Lindgren, R. (2017). Embracing Digital Innovation in Incumbent Firms: How Volvo Cars Managed Competing Concerns. MIS Q., 41(1), 239-253.

Teece, D. J. (2010). Business Models, Business Strategy and Innovation. Long Range Planning, 43(2-3), 172-194.

Teece, D. J. (2018). Profiting from Innovation in the Digital Economy: Enabling Technologies, Standards, and Licensing Models in the Wireless World. Research Policy, 47(8), 1367-1387.

Tiutiunyk, I., Drabek, J., Antoniuk, N., Navickas, V., Rubanov, P. (2021). The Impact of Digital Transformation on Macroeconomic Stability: Evidence from EU Countries. Journal of International Studies, 14(3).

Verhoef, P. C., Broekhuizen, T., Bart, Y., Bhattacharya, A., Qi Dong, J., Fabian, N., Haenlein, M. (2021). Digital Transformation: A Multidisciplinary Reflection and Research Agenda. Journal of Business Research, 122, 889-901.

Wiktor, J. W., Dado, J., Simberova, I. (2021). The Digital Transformation of the EU Market: The Digital Single Market Strategy in the Context of E-Commerce Development Diversification in Czechia, Poland and Slovakia: Transformacja cyfrowa rynku Unii Europejskiej. Strategia jednolitego rynku cyfrowego a dywersyfikacja rozwoju e-commerce w Czechach, Polsce i Słowacji. Problemy Zarzadzania, 19(1), 11-29.

Wysokińska, Z. (2021). A Review of the Impact of the Digital Transformation on the Global and European Economy: Przegląd wpływu transformacji cyfrowej na gospodarkę światową i europejską. Comparative Economic Research, 24(3), 75-92.

Zhu, F., Furr, N. (2016). Products to Platforms: Making the Leap. Harvard Business Review, 94(4), 72-78. 
